\title{
IDENTIFIKASI DAYA LELEH DAN OVERRUN SERTA ANALISIS KADAR ZAT BESI (FE) ES KRIM DENGAN PENAMBAHAN TEPUNG DAUN KELOR (Moringa Oleifera)
}

\author{
Arwinni Puspitasari' ${ }^{1}$, Fitri Wahyuni' ${ }^{2}$, Suherman $^{3}$, Nur Nikmah S ${ }^{4}$, Syafruddin ${ }^{5}$ \\ Program Studi S1 Gizi, STIKes Salewangang Maros \\ arwinnipuspitasarigizi@gmail.com' fitriwahyuni.am@gmail.com²
}

\begin{abstract}
Moringa leaves are fresh food ingredients so they quickly spoil. Processing Moringa leaves into flour can extend the shelf life of Moringa leaves. Moringa leafflour can be used as a substitute for food processing. The food that is usually consumed by the community is a snack or light snack, one of which is ice cream. Ice cream is a solid food in frozen form that is favored by many people from children, teenagers, adults, to the elderly. This study aims to determine whether there is an effect of melting power, overrun and analysis of iron (Fe) levels of ice cream with the addition of Moringa leaf flour. This type of research is an experiment with 5 ice cream treatments with the addition of Moring a leaf flour 0\%, 5\%, 10\%, 15\%, and 20\%. Analysis of the data used is the One Way Anova test and Duncan Advanced Test, to find the best results from the melting power and overrun of ice cream with the addition of Moringa flour. The best ice cream is chemically tested in the laboratory which includes iron (fe) levels. The results showed 1). There is an effect of melting ice cream with the addition of Moringa leaf flour with a significant value of 0.04 ( $p$ $<0.05)$ 2). There was no significant effect on the overrun of ice cream with the addition of Moringa leaf flour with a significant value of $0.066(p>0.05) 3)$. The best level of iron $(\mathrm{Fe})$ in ice cream is found in the sample addition of 5\% Moring a leafflour, which is 0.991 ppm. Based on these results, it can be concluded that the best melting power is found in X1 ice cream with the addition of 5\% Moringa leaf flour with a melting time of 15 minutes. In this study, chemical tests were carried out on the best product samples based on the melting power test, namely sample X1 with the addition of 5\% Moringa leaf flour, which was 0.991 mg.
\end{abstract}

Keywords $\quad$ : Ice cream, Melting Power, Moringa Oleifera, Overrun, Iron (Fe)

\begin{abstract}
ABSTRAK
Daun kelor merupakan bahan makanan segar sehingga cepat mengalami kerusakan. Pengolahan daun kelor menjadi tepung dapat memperpanjang masa simpan daun kelor. Tepung daun kelor dapat dimanfaatkan sebagai bahan substitusi pembuatan olahan pangan. Pangan yang biasa dikonsumsi masyarakat adalah camilan atau snack ringan salah satunya es krim. Es krim merupakan makanan padat dalam bentuk beku yang banyak disukai oleh masyarakat mulai dari anak-anak, remaja, dewasa, hingga manula. Penelitian ini bertujuan untuk mengetahui apakah ada pengaruh daya leleh, overrun dan analisis kadar zat besi $(\mathrm{Fe})$ es krim dengan penambahan tepung daun kelor. Jenis penelitian ini adalah eksperimen dengan 5 perlakuan es krim dengan penambahan tepung daun kelor $0 \%, 5 \%, 10 \%, 15 \%$, dan 20\%. Analisis data yang digunakan adalah uji One Way Anova dan Uji Lanjutan Duncan, untuk mencari hasil terbaik dari daya leleh dan overrun es krim dengan penambahan tepung kelor. Es krim terbaik diuji kimiawi di laboratorium yang meliputi kadar zat besi (fe). Hasil penelitian menunjukkan 1). Adanya pengaruh daya leleh es krim dengan penambahan tepung daun kelor dengan nilai signifikan $0,04(\mathrm{p}<0,05) 2)$. Tidak terdapat pengaruh nyata terhadap overrun es krim penambahan tepung daun kelor dengan nilai signifikan 0,066 (p>0,05) 3). Kadar zat besi $(\mathrm{Fe})$ es krim terbaik terdapat pada sampel penambahan tepung daun kelor 5\% yaitu 0,991 ppm. Berdasarkan hasil tersebut dapat disimpulkan bahwa, daya leleh terbaik terdapat pada es krim X1 dengan penambahan tepung daun kelor 5\% dengan waktu pelelehan 15 menit. Dalam penelitian ini uji kimia
\end{abstract}


dilakukan pada sampel produk terbaik berdasarkan uji daya leleh yaitu sampel X1 dengan penambahan tepung daun kelor $5 \%$ yaitu $0,991 \mathrm{mg}$.

Kata Kunci : Daya Leleh, Es Krim, Overrun, Zat Besi (Fe)

\section{PENDAHULUAN}

Menurut hasil penelitian, daun kelor mengandung vitamin $\mathrm{A}$, vitamin $\mathrm{C}$, Vit $\mathrm{B}$, kalsium, kalium, besi, dan protein, dalam jumlah sangat tinggi yang mudah dicerna dan diasimilasi oleh tubuh manusia. Daun kelor adalah daun dari pohon kelor yang mengandung berbagai zat gizi makro dan mikro serta bahan-bahan aktif yang bersifat sebagai antioksidan. Mengandung nutrisi penting seperti zat besi (fe) $28,2 \mathrm{mg}$, kalsium (ca) 2003,0 mg dan vitamin A 16,3 mg kaya $\beta$ karoten, protein, vitamin A, C, D, E, K, dan B (tiamin, riboflavin, niasin, asam pantotenat, biotin, vitamin B6, vitamin B12, dan folat). Berbagai jenis senyawa antioksidan seperti asam askorbat, flavonoid, fenolat dan karotenoid. Kelor pun digunakan sebagai bahan utama ratusan obat, baik untuk pencegahan maupun pengobatan penyakit berdasarkan analisa yang telah dilakukan salah satunya anemia defisiensi besi (Savitri, 2016).

Salah satu upaya untuk mencegah terjadinya anemia defisiensi besi adalah memanfaatkan potensi pangan lokal yang mudah dijangkau oleh masyarakat luas. Tanaman kelor merupakan tanaman yang banyak tumbuh di negara tropis termasuk Indonesia khususnya di Provinsi Sulawesi Selatan, Kabupaten Maros. Tanaman kelor ini sering dikonsumsioleh masyarakat dalam bentuk sayuran. Namun kini daun kelor seperti terlupakan seiring banyaknya ragam makanan. Padahal tanaman ini banyak mengandung manfaat dan mengandung zat gizi yang begitu tinggi serta dapat dijadikan sebagai produk yang unggul seperti es krim (Nikita et al. 2018).

Menurut hasil penelitian Zakaria, (2012) terhadap komposi kandungan gizi dalam 100 gr tepung daun kelor veritas Sulawesi mengandung protein $28.25 \%$, vitamin A dalam bentuk betakaroten $11.92 \mathrm{mg}$, kalsium $2241.19 \mathrm{mg}$, zat besi $35.91 \mathrm{mg}$, dan magnesium sebanyak $28.03 \quad \mathrm{mg}$, mengkonsumsi daun kelor merupakan alternatife untuk menanggulangi masalah gizi di Indonesia. Tepung daun kelor mengandung senyawa mineral yang cukup tinggi berfungsi sebagai bahan pangan fungsional untuk mengatasi anemia.

Tepung daun kelor dapat dimanfaatkan sebagai bahan substitusi pembuatan olahan pangan. Pengolahan daun kelor menjadi tepung dapat memperpanjang masa simpan daun kelor. Salah satu pangan yang biasa dikonsumsi masyarakat adalah camilan atau snack ringan. Oleh karena itu, daun kelor dapat diolah menjadi tepung daun kelor dan dapat diolah menjadi aneka produk olahan berbahan dasar tepung daun kelor. Salah satu produk olahan tepung daun kelor yang terkenal di semua lapisan masyarakat adalah es krim (Krisnadi, 2015).

Es krim merupakan jenis makanan padat yang dibuat dengan cara pembekuan tepung es krim atau dari campuran susu, lemak hewani maupun nabati, gula, dengan atau tanpa bahan makanan lain dan bahan makanan yang diizinkan. Banyak upaya yang dilakukan produsen untuk menghasilkan karakteristik es krim yang disukai oleh konsumen (SNI, 1995). Karakteristik es krim juga ditentukan oleh beberapa sifat fisik yang dikehendaki seperti viskositas, tekstur, resistensi pelelehan, pengembangan volume (overrun), dan total padatan (Anugrah, 2020)

Menurut Padaga dan Sawitri, (2005) daya leleh merupakan waktu yang dibutuhkan es krim untuk meleleh sempurna. Es krim yang 
berkualitas tinggi tidak cepat meleleh saat dihidangkan pada suhu kamar. Daya leleh pada es krim dapat dipengaruhi oleh bahan baku es krim seperti protein, padatan dan bahan penstabil. Selain itu proses pembuatan seperti homogenisasi dapat mempengaruhi kecepatan meleleh es krim. Homogenisasi yang kurang tepat menyebabkan penyebaran lemak kurang merata membuat tekstur menjadi kasar dan overrun meningkat. Hal ini sesuai dengan teori flores, dkk (1992) yang menyatakan bahwa resistensi pelelehan yang baik pada es krim berkisar antara 10-15 menit.

Pengembangan volume es krim disebut overrun, yaitu bertambahnya volume karena terjadinya pemerangkapan udara ke dalam adonan es krim saat pengadukan. Proses agitasi akan membentuk rongga udara yang terlepas bersamaan dengan melelehnya es. Semakin tinggi overun akan menghasilkan es krim dengan tekstur seperti salju (spongy). Menurut (SNI, 1995) bahwa standar overrun es krim yang baik menurut industri rumah tangga biasanya berkisar antara 35-50\%.

Berdasarkan uraian diatas menggambarkan penulis tertarik untuk melakukan penelitian dengan judul "Identifikasi daya leleh dan overrun serta kadar zat besi (fe) pada es krim dengan penambahan tepung daun kelor" Adapun tujuan dari penelitian ini adalah untuk mengetahui apakah ada pengaruh daya leleh, overrun dan analisis kadar zat besi (Fe) es krim dengan penambahan tepung daun kelor.

\section{METODE}

Metode yang digunakan dalam penelitian ini adalah metode eksperimen. Perlakuan yang diberikan adalah es krim dengan penambahan tepung daun kelor dengan 5 perlakuan dan 3 ulangan. Eksperimen pertama menggunakan $0 \%$ penambahan tepung daun kelor, eksperimen kedua menggunakan 5\% (10 gr) penambahan tepung daun kelor, eksperimen ketiga menggunakan $10 \%$

$\left(\begin{array}{ll}20 & \text { gr}\end{array}\right)$ penambahan tepung daun kelor, eksperimen keempat menggunakan $15 \%$ (30 gr) dan eksperimen kelima penambahan tepung daun kelor 20\% (40 gr) penambahan tepung daun kelor.

Penelitian ini telah dilaksanakan pada bulan Juli - Agustus 2020 di Laboratorium Kuliner STIKes Salewangang Maros untuk pembuatan tepung daun kelor, es krim, uji daya leleh dan uji overrun, sementara untuk analisis zat besi (fe) es krim daun kelor dilakukan di Sekolah Menengah Teknologi Industri (SMTI).

\section{HASIL}

Hasil uji daya leleh es krim kelor menunjukkan rata-rata waktu kecepatan meleleh es krim berkisar antara 11,97 menit/gram - 26,18 menit/gram. Rata - rata waktu kecepatan meleleh es krim dari semua perlakuan di tunjukkan pada tabel 1 .

Tabel 1. Nilai Rata - Rata Kecepatan Meleleh Es Krim Penambahan Tepung Daun Kelor

\begin{tabular}{|c|c|c|c|c|}
\hline \multirow[t]{2}{*}{ Perlakuan } & \multicolumn{3}{|c|}{ Pengulangan } & \multirow{2}{*}{$\begin{array}{c}\text { Rata-rata } \\
\text { (menit/gram) }\end{array}$} \\
\hline & I & II & III & \\
\hline $\mathrm{X} 0$ & 12,53 & 11,24 & 12,15 & 11,97 \\
\hline $\mathrm{X} 1$ & 13,42 & 16,02 & 18,08 & 15,84 \\
\hline $\mathrm{X} 2$ & 20,24 & 13,16 & 27,26 & 20,22 \\
\hline $\mathrm{X} 3$ & 29,26 & 19,49 & 21,36 & 23,37 \\
\hline $\mathrm{X} 4$ & 32,15 & 18,27 & 28,13 & 26,18 \\
\hline
\end{tabular}

Sumber : Data primer 2020

Keterangan:

Kontrol = Es krim tanpa penambahan tepung kelor.

$\mathrm{X} 1=$ Es krim penambahan tepung kelor 5\%

$\mathrm{X} 2=$ Es krim penambahan tepung kelor

$10 \%$

$\mathrm{X} 3=$ Es krim penambahan tepung kelor

$15 \%$

$\mathrm{X} 4=$ Es krim penambahan tepung kelor $20 \%$

Berdasarkan tabel 1 diatas menunjukkan 
kecepatan meleleh tertinggi (waktu yang paling lama) terdapat pada penambahan tepung daun kelor 20\% dengan waktu 26,18 menit/gram, sedangkan kecepatan meleleh terendah (waktu paling cepat) terdapat pada es krim dengan penambahan tepung daun kelor $0 \%$ dengan waktu $11,97 \%$ menit/gram.

Hasil uji overrun es krim penambahan tepung daun kelor menunjukkan rata-rata nilai overrun dari 3 kali pengulangan perlakuan $\mathrm{X} 0$ X4 antara $38,80 \%$ - 46,44\% . Rata - rata nilai overrun dari semua perlakuan di tunjukkan pada tabel 2 .

Tabel 2. Nilai Rata - Rata Overrun Es Krim Penambahan Tepung Daun Kelor

\begin{tabular}{ccccc}
\hline Perlakuan & \multicolumn{3}{c}{ Pengulangan } & Rata-rata \\
\cline { 2 - 4 } & I & II & III & \\
\hline X0 (0\%) & 39,30 & 42,74 & 36,00 & 38,80 \\
X1 (5\%) & 37,33 & 35,27 & 37,08 & 36,56 \\
X2 (10\%) & 38,96 & 39,28 & 37.47 & 38,23 \\
X3 (15\%) & 40,58 & 30,52 & 39.60 & 36,56 \\
X4 (20\%) & 51,11 & 39,47 & 49.74 & 46,44 \\
\hline
\end{tabular}

\section{Sumber : Data primer 2020}

Keterangan:

Kontrol = Es krim tanpa penambahan tepung kelor.

$\mathrm{X} 1=$ Es krim penambahan tepung kelor $5 \%$

$\mathrm{X} 2=$ Es krim penambahan tepung kelor $10 \%$

$\mathrm{X} 3=$ Es krim penambahan tepung kelor $15 \%$

$\mathrm{X} 4=$ Es krim penambahan tepung kelor 20

Berdasarkan tabel 2 diatas menunjukkan nilai rata-rata Overrun es krim dengan penambahan tepung daun kelor yaitu nilai overrun tertinggi adalah perlakuan $\mathrm{X} 4$ dengan nilai $46,44 \%$ dan nilai overrun terendah adalah perlakuan X1 dan X3 dengan nilai 36,56\%.

Hasil uji kimia dilakukan pada sampel produk terbaik berdasarkan uji daya leleh yaitu es krim X1 dengan penambahan tepung daun kelor $5 \%$. Kandungan zat besi (Fe) es krim penambahan tepung daun kelor dapat dilihat pada tabel 3 .

Tabel 3. Hasil Analisis Kandungan Zat Besi (Fe) pada Es Krim Penambahan Tepung Daun Kelor

\begin{tabular}{cc}
\hline Sampel & $\begin{array}{c}\text { Fe } \\
(\mathbf{m g}) / \mathbf{1 0 0} \text { gr }\end{array}$ \\
\hline \multirow{2}{*}{ 1 } & 0,985 \\
& 0,984 \\
& 1,003 \\
& 0,991
\end{tabular}

\section{Sumber : Data primer 2020}

Keterangan:

$\mathrm{X} 1=$ Es krim penambahan tepung kelor 5\%

Berdasarkan tabel 3. Hasil analisis zat besi (fe) pada es krim penambahan tepung daun kelor pada sampel X1 (5\%) dilakukan sebanyak 3 kali pengulangan berturut - turut adalah $0,985,0,984,1,003 \mathrm{mg}$, dengan ratarata $0,991 \mathrm{mg}$.

\section{PEMBAHASAN}

Daya leleh adalah kemampuan mencairnya es krim dalam waktu tertentu. Kemampuan ini akan mempengaruhi kenampakan es krim. Es krim dapat dikatakan baik pada saat pelelehan apabila sifat es krim tersebut sama dengan awal adonan es krim yang dibuat. Biasanya kecacatan pada resistensi atau pelelehan sering terjadi yang ditandai dengan timbulnya buih. Hal ini dikarenakan banyaknya udara dan jumlah zat padat yang tinggi.

Dalam penelitian ini daya leleh terbaik terdapat pada es krim X1 dengan penambahan tepung daun kelor 5\% dengan waktu pelelehan 15 menit, hal ini sesuai dengan pendapat flores, dkk (1992) yang menyatakan bahwa resistensi pelelehan yang baik pada es krim berkisar antara 10-15 menit.

Es krim yang baik akan lebih tahan terhadap suhu ruangan saat dihidangkan. 
Kecepatan meleleh es krim dipengaruhi oleh bahan-bahan yang digunakan, karena bahan utama yang digunakan adalah whipped cream pada suhu ruang asam lemak tidak jenuh akan berwujud cair, sedangkan asam lemak jenuh akan berwujud padat, lemak susu memiliki titik cair pada suhu $38^{\circ} \mathrm{C}$ (Buckle et al dlam Masykuri dkk, 2012).

Tingkat leleh dari es krim sangat mempengaruhi kualitas dari es krim itu sendiri. Es krim yang mudah meleleh ataupun yang terlalu keras tidak disukai oleh konsumen. Konsumen menginginkan es krim yang memiliki permukaan yang lembut namun tidak mudah lumer (Widiantoko, 2011).

Semakin banyak penambahan daun kelor maka kecepatan meleleh es krim akan semakin lambat, karena daun kelor berfungsi sebagai bahan kering tanpa lemak (BKTL) yang membuat es krim menjadi kental dan memperlambat waktu pelelehan es krim. Kelelehan es krim disebabkan karena terjadinya penurunan titik beku pada es krim. Waktu yang dibutuhkan es krim untuk meleleh sangat dipengaruhi oleh komposisi bahan yang digunakan dalam pembuatan es krim. (Sawitri dan Padaga, 2015)

Daun kelor adalah bahan pengganti bahan kering tanpa lemak (BKTL) yang digunakan dalam pembuatan es krim dengan kandungan protein yang dapat berfungsi untuk menghambat kecepatan meleleh dan juga kandungan lemak yang ada yang berfungsi memberikan bentuk dan kepadatan, serta memberikan sifat meleleh yang baik. selain itu protein yang terkandung didalamnya juga berfungsi dalam menstabilkan emulsi lemak setelah proses homogenisasi dan menghasilkan tekstur es krim yang lembut. Kadar lemak pada es krim juga dapat berakibat terhadap semakin lama waktu pelelehan, bila kadar lemak pada es krim itu rendah dapat mengakibatkan resistensi es krim menjadi lebih cepat (Buckle et al dlam Masykuri dkk, 2012).

Dalam Penelitian ini hasil sidik ragam presentasi uji daya leleh menunjukkan bahwa terdapat pengaruh nyata daya leleh es krim dengan penambahan tepung daun kelor dengan nilai signifikansi $0,04(\mathrm{p}<0,05)$. Penelitian ini sejalan dengan Wijayanti, Ismawati, (2016) dan Septiani, (2018) hasil penelitian menunjukkan $\mathrm{p}=0,000(<0,05)$ yang berarti ada pengaruh nyata terhadap kecepatan meleleh es krim kelor.

Dalam penelitian ini overrun terbaik terdapat pada semua sampel yaitu X0 dengan nilai overrun $38,80 \%$, X1 dengan nilai overrun $36,56 \%$, X2 dengan nilai overrun 38,23\%, X3 dengan nilai overrun $36,56 \%$, dan $\mathrm{X} 4$ dengan nilaii overrun $46,44 \%$. Sesuai dengan teori menurut (SNI, 1995) bahwa standar overrun es krim yang baik menurut industri rumah tangga biasanya berkisar antara 35-50\% (SNI, 1995). Sebagaimana yang dijelaskan oleh Hubeis (1995) bahwa nilai overrun es krim dipengaruhi oleh faktor-faktor proses pembuatan dan komposisi es krim seperti kadar lemak.

Menurut Ivan et al. (2017), pemerangkapan udara terjadi pada saat churning (pengadukan) sehingga menghasilkan overrun yang ditandai dengan munculnya buih-buih kecil di dalam adonan. Jika stabilizer yang ditambahkan dengan konsentrasi tinggi maka pembentukan rongga udara yang besar dan tidak seragam dapat dicegah. Dengan ukuran rongga udara yang kecil dan seragam, transfer panas ke dalam adonan merata sehingga laju pelelehan menjadi lebih lambat.

Menurunnya nilai overrun menyebabkan kandungan air yang terikat dalam adonan es krim meningkatkan tegangan permukaan sehingga udara sulit menembus permukaan adonan dan pengembangan es krim lebih sedikit. Overrun merupakan parameter yang sangat penting dalam pembuatan es krim karena dapat menentukan tingkat harga. Jika overrun es krim yang dihasilkan tinggi maka keuntungan yang diperoleh juga akan tinggi. 
Overrun yang rendah $(<30 \%)$ akan membuat es krim beku menjadi keras, sedangkan overrun yang tinggi (>140\%) menyebabkan es krim menjadi terlalu lunak. Hal ini menunjukkan overrun mempunyai pengaruh besar pada tekstur dan body es krim yaitu terlalu banyak udara akan menghasilkan es krim seperti salju dan di mulut lebih cepat terjadinya pencairan, terlalu sedikit udara menghasilkan produk yang kasar (Anjarsari, 2010). Overrun merupakan komponen penting dalam es krim, jika es krim tidak memiliki overrun, akan berbentuk seperti gumpalan massa yang keras (Hakim dkk., 2012).

Dalam penelitian ini hasil sidik ragam presentasi uji daya leleh menunjukkan bahwa tidak terdapat pengaruh nyata overrun es krim dengan penambahan tepun daun kelor dengan nilai signifikansi 0,066 ( $p>0,05)$. Penelitian ini sejalan dengan hasil penelitian Septiani, (2018) hasil penelitian menunjukkan $\mathrm{p}=0,06$ $(>0,05)$ yang berarti tidak ada pengaruh nyata terhadap overrun es krim penambahan tepung daun kelor.

Zat besi merupakan elemen mikro yang essensial dan diperlukan oleh tubuh dalam pembentukan darah yaitu dalam sistem hemoglobin. Besi dalam makanan yang dikonsumsi berada dalam bentuk ikatan ferri (umumnya dalam pangan nabati) maupun ikatan ferro (umumnya dalam pangan hewani). Fungsi utama besi adalah bersama-sama dengan protein dan tembaga membentuk sel darahmerah (hemoglobin). Besi juga meningkatkan kualitas darah dan meningkatkan ketahanan terhadap stress dan penyakit (Andarwulan dkk, 2011).

Dalam penelitian ini uji kimia dilakukan pada sampel produk terbaik berdasarkan uji daya leleh yaitu es krim X1 dengan penambahan tepung daun kelor 5\% (10 gr). Analisis kadar zat besi (Fe) pada sampel X1 nilai rata - rata dari sampel tersebut yaitu 0,991 mg, dibandingkan dengan hasil penelitian Wijayanti, Ismawati, (2016) kadar zat besi $(\mathrm{Fe})$ es krim kelor dengan penambahan tepung 20 gram yaitu 6,09 $\mathrm{ppm}$. Dapat disimpulkan bahwa kandungan zat besi $(\mathrm{Fe})$ dengan penambahan daun kelor 5\% lebih rendah dibandingkan dengan penambahan tepung kelor 20 gram.

Hasil perhitungan kadar zat besi es krim dengan penambahan tepung daun kelor menggunakan TKPI PERSAGI, (2017) pada sampel X0 (kontrol) yaitu $0,3 \mathrm{mg}$. Adapun hasil penelitian dari Dhafir, Laenggeng, (2020) tentang pembuatan tepung kelor hasil kadar zat besi $(\mathrm{Fe})$ dengan sampel $5 \mathrm{mg}$ tepung kelor di dapatkan nilai rata-rata dari 3 kali pengulangan yaitu $1,25 \mathrm{ppm}$. Dapat disimpulkan bahwa hasil penelitian es krim dengan penambahan tepung daun kelor 5\% tidak jauh beda dengan hasil kadar zat besi (Fe) pada hasil penelitian pembuatan tepung kelor.

Semakin tinggi penambahan tepung daun kelor maka semakin tinggi pula kandungan zat besinya, hal ini disebabkan karena kandungan zat besi dalam 100 gram daun kelor yaitu $7 \mathrm{mg}$, apabila ditepungkan menjadi 28,2 mg (Sari, dkk, 2017). Berdasarkan besar kandungan zat besi pada tepung daun kelor mempunyai pengaruh peningkatan zat besi pada es krim penambahan tepung daun kelor.

\section{KESIMPULAN}

Dalam penelitian ini daya leleh terbaik terdapat pada es krim X1 dengan penambahan tepung daun kelor 5\% dengan waktu pelelehan 15 menit. Terdapat pengaruh nyata daya leleh es krim dengan penambahan tepung daun kelor dengan nilai signifikansi $0,04(\mathrm{p}<0,05)$. Dalam penelitian ini nilai overrun terbaik terdapat pada semua sampel yang diteliti yakni $8,80 \%$ (X0), 36,56\% (X1), 38,23\% (X2), 36,56\% (X3), 46,44\% (X4). Tidak terdapat pengaruh nyata overrun es krim dengan penambahan tepun daun kelor dengan nilai signifikansi 0,066 ( $p>0,05$ ). Dalam penelitian ini uji kimia dilakukan pada sampel produk terbaik berdasarkan uji daya leleh yaitu sampel X1 
dengan penambahan tepung daun kelor 5\% yaitu $0,991 \mathrm{mg}$.

\section{UCAPAN TERIMAKASIH}

Peneliti mengucapkan terimakasih terutama kepada kedua orangtua, dosen pembimbing dan semua pihak yang terlibat dalam penelitian ini baik secara langsung maupun tidak langsung. Semoga penelitian ini dapat bermanfaat bagi pembaca.

\section{DAFTAR PUSTAKA}

Andarwulan, N. Kusnandar, F, Herawati, D. 2011. Analisis Pangan, Dian Rakyat. Jakarta.

Anugrah O. 2020. Nilai Overrun , Kecepatan Leleh Dan Kadar Betakaroten Es Krim Susu Sapi Dengan Penambahan Pure Labu Kuning Nilai Overrun, Kecepatan Leleh Dan Kadar Penambahan Pure Labu Kuning.

Dhafir Fatmah, Laenggeng Abd hakim. 2020. Kandungan Kalsium ( $\mathrm{Ca}$ ) dan Zat Besi (Fe) Daun Kelor (Moringa Oleifera). Jurnal Kreatif Online. 8 (1).

Flores, R.J. Kliptel dan J. Tobias, 1992. Ice Cream and Frozen Dessert. In: Dairy Science and Technology Series. Handbook 3.Y.H Hui (ed). VHC Publisher Inc, New York.

Hubeis, M. 1995. Paket Industri Pangan Es Krim Ekonomi Skala Industry Kecil. Bulletin Fakultas Teknologi Industri Pangan. Institut Pertanian Bogor, Bogor. Vol VII (I). Hal 100-102.

Krisnadi, A. D. (2015). Kelor Super Nutrisi. Pusat Informasi Dan Pengembangan Tanaman Kelor Indonesia, Lembaga Swadaya Masyarakat Media Peduli Lingkungan, Blora.

Masyukuri, Pramono. Y. B, Ardilla D. 2012. Resistensi Pelelhan, Overrun, dan Tingkat Kesukaan Es Krim Vanilla yang terbuat dari Bahan Utama Kombinasi
Krim Susu dan Santan Kelapa. Jurnal Apliaksi Teknologi Pangan. 1(3).

Nikita, Citra Bella et al. 2018. "Haice Moringa (Health Of Ice Cream) Inovasi Produk Olahan Daun Kelor (Moringa) Sebagai Prospek Bisnis Mahasiswa Yang Menjanjikan. "Seminar Nasional Hasil Pengabdian: 9-1.

Sari, K. Y. dan Adi, C. A. 2017. Daya Terima Kadar Protein dan Zat Besi Cookies Subsitusi Tepung Daun Kelor dan Tepung Kecambah Kedelai. Jurnal Media Gizi Indonesia 17(1): 27-33.

Septadina, I.S, Murti, K, Utari, N (2018) Efek Pemberian Ekstrak Daun Kelor (Moringaoleifera) Dalam Proses Menyusui Sriwijya Journal Of Medicine, 1 (1), Januari 2018, 74-79.

Septiani Tan Mariska. 2018. Pengaruh Subsitusi Jali dan Penambahan Tepung Daun Kelor (Moringa Oleifera) Terhadap Karakteristik Fisikokimia dan Sensoris Es Krim Nabati. Universitas Katolik asaoegijapranata. Semarang.

SNI, 1995. Es Krim. Badan Standar Nasional, SNI 01-3713-1995.

Widiantoko. R. K. 2011. Es Krim. Fakutas Tejnologi Pertanian Universitas Jember.

Wijayanti, S.S \& Ismawati. R. 2016. Pengaruh Jumlah Susu Skim dan Daun Kelor (Moringa oleifera) Terhadap Sifat Organoleptik dan Kecepatan Meleleh Es Krim. E-Journal Boga, 5(3), 101-109. 